Kansas State University Libraries

New Prairie Press

\title{
The Inevitability of Playing Politics as Chair: Advantages and Pitfalls
}

Domenick J. Pinto

Sacred Heart University, pintod@sacredheart.edu

Follow this and additional works at: https://newprairiepress.org/accp

Part of the Educational Leadership Commons, and the Higher Education Administration Commons (c) (1) (2)

This work is licensed under a Creative Commons Attribution-Share Alike 4.0 License.

\section{Recommended Citation}

Pinto, Domenick J. (2016). "The Inevitability of Playing Politics as Chair: Advantages and Pitfalls," Academic Chairpersons Conference Proceedings. https://newprairiepress.org/accp/2016/Leadership/19

This Event is brought to you for free and open access by the Conferences at New Prairie Press. It has been accepted for inclusion in Academic Chairpersons Conference Proceedings by an authorized administrator of New Prairie Press. For more information, please contact cads@k-state.edu. 


\section{The Inevitability of Playing Politics as Chair: Advantages and Pitfalls}

\section{Description}

When one thinks of politics in the workplace, especially in the role of academic leadership, images of back-stabbing, insincerity, compromising one's integrity and selling one's colleagues short are often what come to mind. As a chair for 29 years in a department that is rapidly growing, I have continually found that politics is both a necessity and a method of survival that must be navigated through carefully and deliberately.

I continually see the role of chair become increasingly managerial and administrative whereby we are now often intimately involved in strategic planning (departmental, college and universitywide), budget, fundraising, managing conflict, student retention, motivating and encouraging faculty to achieve academic excellence while maintaining scholarship and research, and leading change while maintaining our own standards of excellence in the classroom and in research. Much of this involves contention for resources and having the needs of one's department and faculty heard. Playing politics can be a way to assist a chair in successfully navigating through it all. Although playing politics is often perceived as playing "dirty", it needn't be.

\section{Keywords}

politics, leadership, conflict, administration, managerial, excellence, retention, strategic planning, faculty 


\title{
The Inevitability of Playing Politics as Chair: Advantages and Pitfalls
}

\author{
Domenick Pinto, Chairperson \\ Department of Computer Science, Sacred Heart University
}

\begin{abstract}
Politics is a term often frowned upon as it pertains to the role of an academic leader. However as chair for almost 29 years it has become an essential yet sometimes unwanted aspect of the daily rigors of the position. This paper explores the advantages and pitfalls of "playing politics" as a department chair.
\end{abstract}

\section{Introduction}

When one thinks of politics in the workplace, especially in the role of academic leadership, images of back-stabbing, insincerity, compromising one's integrity and selling one's colleagues short are often what come to mind. As a chair for 29 years in a department that is rapidly growing, I have continually found that politics is both a necessity and a method of survival that must be navigated through carefully and deliberately.

I continually see the role of chair become increasingly managerial and administrative whereby we are now often intimately involved in strategic planning (departmental, college and universitywide), budget, fundraising, managing conflict, student retention, motivating and encouraging faculty to achieve academic excellence while maintaining scholarship and research, and leading change while maintaining our own standards of excellence in the classroom and in research. Much of this involves contention for resources and having the needs of one's department and faculty heard. Playing politics can be a way to assist a chair in successfully navigating through it all. Although playing politics is often perceived as playing "dirty", it needn't be.

Turf issues have become the norm in many departments on college campuses as universities diversify their programs and try to maintain both a traditional and innovative menu of course offerings. 


\section{My Background}

I have been at Sacred Heart University for 40 years, of which 35 have been as a FT faculty member ( 5 years as an adjunct in mathematics, 3 years FT in mathematics, 32 years in computer science). During that time I have been a department chair for 29 years as well as the graduate program director for 18 of those years for the MSCSIT (Comp SCI) and the MSCYB (Cyber Security) programs. I am also a past President of the University Academic Assembly. (Faculty governance group)

\section{So what is Politics in Academia?}

\section{NEGATIVE connotations}

1. Backstabbing

2. Fighting for Resources

3. Navigating through pitfalls within one's department

4. Looking for personal gain

5. Selling one's colleagues short

6. Turf Issues

\section{POSITIVE connotations}

1. Doing good for the department

2. Involvement in Strategic Planning

3. Involvement in budget and fundraising

4. Leading academic change

5. Achieving and maintaining academic excellence

6 Having the needs of the department heard

There are a number of reasons why politics often take hold of a situation.

1. Turf issues have become the norm in many departments and divisions on college campuses as universities diversify their programs and try to maintain both a traditional and innovative menu of course offerings;

2. Declining populations in many cases have forced universities to significantly increase their "base". Recruiting international students, non-traditional students, adding nontraditional courses of study and exploring new delivery methods are all part of the new "entrepreneurial" chair position;

3. All of this takes resources often resulting in these turf issues.... Where one stands POLITICALLY CAN make a difference as to HOW these resources are allocated! 


\section{Suggested Ways of handling all of this}

1. Exploring interdisciplinary programs;

2. Sharing resources and gaining support among faculty from other departments and colleges is a positive way to blend politics into the workplace;

3. Working closely with deans, provosts, other senior administrators and even the president (if possible) are ways to put oneself "out there" and showcase the strength and potential of one's program and faculty. Alas this is not always easy to do;

4. One of the most successful ventures I have undertaken is to take part in faculty governance. This is, to me, one of the most productive and honest political ventures where you can serve the university while making your departments needs and concerns known.

\section{My Ten (14) Rules to Navigating Academia Politically}

1. Know YOUR PERSONAL and departmental goals and be honest about them;

2. Find your allies and your "count on people" within your department

3. Be sure your support staff is loyal to you

4. Work with your dean(s), provost, other senior administrators and even the president

5. Know when to give up on an idea

6. Think POSITIVE

7. Don't be afraid to get angry once in a while, it's OK!!!!

8. Try NOT to get personal

9. Always look ahead

10. Do what you can to increase enrollment and revenue in your area

11. Have friends in all colleges and departments

12. DON'T BE AFRAID to ask for something!!! Ask for MORE than you expect!

13. REMEMBER. No one is going to hand you something on a silver platter

14. Be PLEASANT... most of the time! 


\section{Scenarios and how one might handle them}

1. We all know that feeling. One member of a committee (chair or program director) that meets regularly with the dean constantly boasts about theirs and their department's many successes. This can be in the form of revenue generated, scholarly activities, grant money brought in or any number of other "accomplishments". It is understandable that we can expect to hear about these once or twice but that individual somehow always manages to get back on how "wonderful" they are.

\section{SUGGESTION:}

Do your best to ignore it. It is very likely that others feel the same way that you do and hopefully the dean (or other administrator who is chairing the meeting) will tactfully attempt to move forward the discussion and minimize the boasting. If it continues it might be advisable to get several other chairs to set up a meeting with the dean to express the frustrations of the group. It isn't likely that the "guilty" party will respond even if you directly and tactfully point out the annoyance directly to the offender. If however the dean or other administrator does mention it, the situation may improve.

2. Your support staff and administration in the department are conflicted with each other. You have a large department and thus have a total of five non-faculty members performing various tasks such as department assistant, administrative assistant, lab technician, advisor and counselor, and recruiter. They disagree on fundamental office procedures and individually (or in groups of two) often come to you to complain.

\section{SUGGESTION:}

Plan a luncheon or dinner meeting off campus. Try to choose a relaxing atmosphere and indicate that the agenda for the lunch or dinner meeting is for you to get input from all of them on how best to coordinate all aspects of the department's most detailed undertakings. Let them know in advance that you want input and want to maintain a friendly, non-threatening and non-accusatory tone.

Allow everyone to be heard and if possible try to get the group subdivided into 2 smaller groups to work on office police and procedures as well as to propose some solutions to the issues at hand. Stress the importance of communication and compromise and if at all possible try to remain neutral. This is of course not possible if one or more of these people are totally unreasonable. If that is the case speak with them separately as soon as possible to indicate that you cannot tolerate disrespect and unwillingness to compromise. Although this tactic may not remedy every situation it should help to unify at least some aspects of the group's dynamic and also show that you are willing to help however you can. Making your staff and administrators who report to you feel heard and respected will 
go a long way. Let's face it....you absolutely need the support of these people in order for you to do your job. A little kindness and understanding can go a long way.

3. You are proposing a new major venture for the department. This new program is a result of a great deal of work by you and your department and is fully supported by the department. The issue is that your provost is also in full support of it but your dean is not. Part of the reason for this is political but also there is an element of financial risk involved that you realize is valid but most of the market research is favorable for this program. You have a very good relationship with both the dean and provost but this situation clearly puts you in a bind. There is a time constraint on this as well.

\section{SUGGESTION:}

This is a tough one.

I would first set up a meeting with your dean and one or two key faculty from your department to discuss the proposal. Do this on the dean's terms, i.e., based on a time and location suggested by the dean.

Allow plenty of time for the dean to express her(his) concerns, and then present the department's point of view. Ask your faculty in advance to keep it friendly and calm, and solicit suggestions from the dean as to how a modification of the proposal might make it more favorable.

After this meeting ask for a very brief appointment alone with the dean to discuss the situation. If the dean has now become more open to the proposal suggest that the two of you meet over lunch with the provost to discuss next steps. If the dean is still adamant about not supporting the program, ask to revisit it in three to six months. This may work for several reasons:

a) it shows that the program is still very important to you but that you are willing to compromise;

b) it may cause some unhappiness in the department but the hope of revisiting it should sustain most of them;

c) it may very well be that in three to six months other changes may be taking place in the administration

This is a true case of where one has to choose their battles. 


\section{Choosing your Battles and Conclusion}

I have left this very important piece of advice for last. The politics of being chair is all about compromise, open-mindedness and most importantly, choosing one's battles. As said in Dr. Richard Carlson's book of the same name, "Don't sweat the small stuff".

You will have much more credibility and clout if you stand firm on several very important issues and are willing to compromise on most others than if you battle in every situation that comes your way. Always prioritize and pursue what is MOST important to you and your department first.

In summary, keep in mind that no matter how difficult a situation appears to be, often times in the long run things will work out. Keep an open mind, make sure you allow yourself time away from your job, and maintain a sense of humor.

As I often say to my current dean, despite long hours and frustrations on many levels, after 29 years...."I love my job...I love my job...."

And I do. 